\title{
Science, public policy and engagement: Debates on stem cell research in Brazil
}

\author{
LILIANA ACERO ${ }^{1}$
}

\begin{abstract}
This paper analyses the main narratives, rhetorical resources and themes deployed during public contemporary debates on stem cell research (SCR) and cellular therapy in Brazil, an emergent global player. It examines the discursive rhetoric used to discuss adult and embryonic stem cell research and analyses the processes and main themes involved in the approval of the 2005 Biosecurity Law at the National Congress and, more specifically, during the 2007 public hearing at the Federal Supreme Court. Relying on previous academic work and supported by the analysis of public audiences' transcriptions, key journal reports and 15 semi-structured face-to-face interviews, the paper focuses mainly on the common topics in the scientists' narratives to map the characteristics of the Brazilian debates and establish the main convergences and divergences between the positions taken by opposing lobbies. These are illustrated by selected statements on recurrent themes and assumptions. There are three main areas of focus: forms of scientific, technical and moral construction of discourse and regulation; strategies towards civil society's engagement and participation; and the country's contributions to global genetics and health biotechnology. The paper argues that the specificities of the narratives deployed by the different social actors are a product not solely of sociocultural and religious backgrounds and practices, but also of local SRC development and social awareness, of the exercise of citizens' rights, and of prevalent cultural trends in the local relations between science, medicine and society.
\end{abstract}

\section{Introduction}

Stem cell research (SCR) has increasingly become a global activity, ${ }^{2}$ in which initiatives from the industrialised and emerging economies promise important socioeconomic contributions, mainly through the design of new therapies for noninfectious disease that has increased among ageing populations, also within the developing world. ${ }^{3}$ The use of embryonic stem cell lines as an innovation trajectory in research and isolated clinical trials, has given rise to international controversies relating to embryo use and disposal. ${ }^{4}$ These debates are also relevant for: the sustainability of high-risk experimental research in developing countries and for their technological choices, as well as, for the information on health-care the local 'publics' have access to and which they need in order to be able to participate as informed citizens in policy-making. Some of the technologies being researched by industrialised countries are being tested in emerging economies under dubious conditions. ${ }^{5}$ Future technological and regulatory regimes will articulate and influence each other. ${ }^{6}$ 
This paper examines the discursive rhetoric used during public debates on adult and embryonic stem cell research in Brazil and analyses the main themes and contents involved in the approval of the 2005 Biosecurity Law (Lei $\left.n^{\circ} 11.105\right)$ at the National Congress and, more specifically, during the 2007 public hearing (ADIn 3510) at the Federal Supreme Court. The analysis focuses mainly on the common themes found in the scientists' narratives ${ }^{7}$ to map the characteristics of the Brazilian debates and to establish the main convergences and divergences between the positions taken by opposing lobbies and the discourses each of them developed to engage public opinion (illustrated by selected statements on recurrent themes and assumptions). The paper argues that the specificities of the narratives deployed by the different social actors are a product not solely of sociocultural and religious backgrounds and practices, but also of local SRC development and social awareness, of the exercise of citizens' rights, and of prevalent cultural trends in the local relations between science, medicine and society.

\section{Stages in the approval of the Brazilian 2005 Biosecurity Law}

In Brazil, a very long process of negotiation and public debate was required to change the 1995 Biosecurity Law (Lei $\left.n^{\circ} 8.974\right)$ and approve its replacement (Lei $\left.n^{o} 11.105\right)$. The legislative process included the following events: the approval of the first law on biosecurity (the 1995 law), the creation of a National Technical Commission on Biosecurity $^{8}$ and challenges against its decisions on genetically modified organisms (GMOs); the 2003 law reform project; the initial approval of the new law in 2005; a federal legal case declaring its unconstitutionality (ADIn 3510); and its final approval in 2008 .

There were four distinct phases to this approval process, based on different social appraisals on biosecurity and on changing relations between science, medicine and society. ${ }^{9}$ Between 1997 and 2003, under increasing social pressure for regulation, the government sought approval of a law governing transgenic crops and foods. A vacuum of regulatory frameworks had facilitated agribusiness firms' illegal commercialisation of several types of GMOs, mainly soya, cotton and maize. Local stem cell research had begun around 1999, promising many useful results for different medical fields. At that time, health innovation was developing within a generally positive context, due to the creation of the national public health system (Sistema Unico de Saúde - SUS) in 1990, based upon the principle of healthcare for all free at the point of service. A basic trust relationship had been established between science, medicine and society, in spite of certain specific health controversies. ${ }^{10}$

In 2003, the biosecurity law reform project was drafted. At the time, there was no specific federal law- and, indeed, to date there is still no specific law ${ }^{11}$ - to regulate the use of human embryos in research or assisted reproduction, although assisted reproduction has been expanding steadily since the early 1980s. This reform project was seen as an opportunity to negotiate the conditions for the approval of transgenic crops, together with that of embryonic stem cell research (ESCR). ${ }^{12}$ 
During initial negotiations, the legal ban on ESCR, based on Article 6 of the 1995 Biosecurity Law, banning the production, banking and manipulation of human embryos, was upheld. However, the ban was lifted when the 2003 law reform project was sent to the Deputy Chamber of Congress. Those opposing the ban, a majority in number and highly politically influential, reacted strongly. Within the Deputy Chamber of Congress opponents, grouped into two well-organised blocs, namely the Catholics (Bancada Católica) and the evangelicals (Frente Parlamentar Evangélico $F P E$ ) - both aligned with anti-abortion groups - made an agreement to modify the latest draft of the bill, basing their decision on their religious convictions. ${ }^{13}$

Between 2004 and 2005 those in favour of ESCR became better organised. Their lobby was composed mainly of scientists, patient organisations, individual severely ill patients and some (publicly prominent) disabled patients and their relatives, the latter grouped in the main Brazilian patient organisation: MOVITAE (Movimento em Prol da Vida). ${ }^{14}$ The scientific community in favour of ESCR and the other active organisations- including a highly visible group of local patients who could eventually benefit from SCR- formed an alliance with the lobby favourable to the cultivation of GMOs in Brazil, with whom they shared a similar strategy for the approval of regulation relevant to both topics. ${ }^{15}$

Scientists from this lobby were invited to the 2004 public hearing at the Senate Chamber of Congress (one of the two Chambers in Congress, the other being the Deputies' Chamber). They pursued a pragmatic strategy, presenting detailed research reports and making repeated references to 'the opportunity for a humanitarian use' of surplus and unviable frozen embryos in research. These were estimated at between 20-30,000, which later proved to be a major overestimate. Scientists construed the disposal of frozen embryos as an inevitable daily and pre-existing by-product of the work of the fertility clinics, and defended ESCR as important to maintain and improve Brazil's position in the biotechnology race and as a way of reducing public health expenditure in the future. Conceptual and ethical debates on embryo status were avoided, as well as all reference to ethically controversial techniques, such as therapeutic cloning.

Some representatives at the Senate supported the scientists' arguments and expressed their faith in the capacity of the scientists to obtain future benefits, such as those promised by cellular therapies. ${ }^{16}$ They considered scientific narratives to be neutral and attributed unique authority to them, vis-à-vis other forms of knowledge, as had been the case during previous discussions on GMOs.

The 2004 Senate debate changed the balance of forces in Congress. During the last vote on the law in the Chamber of Deputies on 2 March 2005, many of the Christian deputies, especially the evangelicals, were already favourable towards the liberalisation of ESCR and the law was finally approved with 366 votes in favour and only 59 votes against. 


\section{'Unconstitutionality': The Brazilian 2007 Federal Supreme Court hearing}

On 16 May 2005, soon after the approval of the new law, the Brazilian attorneygeneral Claudio Fonteles, a self-declared Catholic, filed a lawsuit (ADIn 3510) in the Federal Supreme Court (STF) declaring the law unconstitutional mainly because of its Article 5, which established the conditions under which ESCR was allowed to be carried out. These were apparently considered too liberal by the anti-ESCR lobby, whose central assumption, that human life begins at conception, for them a moral and religious conviction, was shared by the attorney-general.

Article 5 of the approved law authorised the derivation of ESC from surplus embryos from in vitro fertilisation, if frozen for three or more years at the date of publication of the law; in-vitro embryos not yet frozen at that date could be used for research only after a three-year freezing period. The law also established the need for parental written informed consent $\left(\right.$ Art. $5^{\circ}, \S 1^{\circ}$ ) and for research institutes and health services working with ESC to submit their projects for approval to the relevant research ethics boards $\left(\right.$ Art. $\left.5^{\circ}, \S 2^{\circ}\right) .^{17}$

M. Fonteles presented an ethical/legal statement: that life begins at fertilisation, and then asked the Supreme Court to answer the question: When does life begin? The lawsuit's argument, based upon the assumption mentioned, was that to accept research experimentation with human embryos was to hamper with the constitutional right to life. Between 2005 and 2007, research in the area continued intermittently with little public financial support and within a highly uncertain context.

\section{Format and Implementation}

The presiding justice, Carlos Ayres Britto, a practising Catholic, decided to hold a public hearing on 24 April 2007, the first in the STF's history, ${ }^{18}$ in order to: "listen to presentations from people with experience and authority". ${ }^{19}$ Explicitly, the hearing was intended to address the STF's doubts, widen its technical knowledge and increase civil society's participation in a socially relevant topic. Implicitly, the hearing was intended to increase the legitimacy of the STF's decisions. ${ }^{20}$

Twenty-two specialists were selected to present 20-minute individual research reports. These scientists were equally divided into two well-characterised opinion blocs: one against and one favourable to the lawsuit. A debate strategy was followed that conflated those against and in favour of the lawsuit with those against and in favour of ESCR. This arrangement was effectively a political strategy, as there could be only two sets of 'valid' opinions expressed among those scientists engaged in this specific debate on SCR in Brazil.

Each bloc was assigned a little over two hours for presentations. ${ }^{21}$ There was no room for debate after each presentation or after each bloc's contributions; the discussion of ideas, views and positions was explicitly dissuaded, as part of the rules of proceedings of the STF on public hearings. The participants were not free to raise questions; they 
were there to answer the questions posed by the public attorney in the lawsuit and to inform the justices about facts and ethical/moral positions related to these questions.

However, some justices characterised the hearing as:

... a House for the People, th e same as Congress. A p lace where different social desires and political, ethical and religious pluralism finds a place in the debates ... Public Hearings ... turn this Court into a democratic space. An open space for reflection and legal and moral argumentation with broad repercus sions upon 'the collective' and within democratic institutions (Justice Gilmar Mendes, a liberal lawyer and a Catholic by background) ${ }^{22}$

... such a vivid and rich discussion ... a $\mathrm{m}$ echanism of participatory or direct democracy ... Metaphoric ally, democracy involves giving a voice to all, m oving those who are us ually seated into the stage of collective decision-making (Justice Carlos Ayres Britto, a lawyer and poet, ${ }_{23}$ president of the public hearing and a practising Catholic).

The format of the hearing hampered the very practice that defines public debate, and was shaped in ways distant from "an example of democracy" ${ }^{24}$; notwithstanding its value as a deliberative, informational and educational tool. The "stage of collective decision-making" ${ }^{25}$ was occupied by the justices, with the support of a new epistemic scientific group. ${ }^{26}$ The strategy adopted was not necessarily the best one to obtain a democratically negotiated consensus for collective decision-making.

Civil society's actual engagement preceded the public hearing. NGO representatives and patients made trips to Brasilia, camped and convened meetings in front of the Supreme Court building, published reports in key national newspapers and on the web sites of participating organisations, and were interviewed on TV.

Social actors' initiatives tend to reflect the different civic epistemologies of the culture where the debate takes place. ${ }^{27}$ In the Brazilian case, they expressed contradictory and ambivalent social and moral/ethical beliefs within a culture undergoing a transition towards a more inclusive democracy.

\section{Definitions of human life and of science}

Ontological perspectives on the beginnings of human life and on the status of the embryo, perspectives that had been relatively silenced by ESCR supporters towards the end of the 2005 law approval process, were brought to the forefront at the public hearing. The two central questions asked by the justices were about the definition of unviable research embryos and about the ideal freezing period for embryos.

The different meanings of human 'life' were obscured in the specialists' presentations. Polarities between 'good' and 'bad' science and 'science' and 'nonscience' were used to mask those meanings, and also to create new boundaries for the 
ESCR field. For example, when the importance of the three-year freezing period for research embryos was discussed, frontier-lines were drawn in each camp using opposite framings: the rights of the parents versus the rights of the embryo. ESCR supporters argued in terms of the ideal time for the parents to make an informed and definite decision on embryo donation. By contrast, their opponents argued that establishing a fixed period was intended to avoid the cloning of research embryos, as well as, embryo commerce and research fraud.

ESCR opponents also expressed a perspective of nature as 'untouched' by culture, contrary to contemporary views on the mutual co-construction between nature and culture and of scientific facts. ${ }^{28}$

When working from within nature's approach is abandoned, all other definitions become arbitrary and there is a lack of any framework to take any decision (Lenize Aparecida Martins Garcia, a biologist and professor and a practising Catholic). ${ }^{29}$

This camp also tried to discredit their adversaries' position on the decrease in frozen embryos' viability for human reproduction over time, through repeated reference to successful reports on Brazilian children born as a result of in-vitro fertilisation using embryos frozen for periods between six and 12 years $^{30}{ }^{31}$. ESCR opponents also argued that the division between viable and unviable embryos led to an inappropriate classification into two types of people: normal and inadequate.

Meanwhile, ESCR supporters characterised life as relational, gradual and in evolution, severing all its connections with embryo life. They also supported research on embryos selected through an 'objective' embryo-grading at the in-vitro fertilisation clinics $^{32} 33$.

Each group was suspicious of the data, evidence and scientific methods of the opposing bloc. ESCR opponents grounded their concerns about embryo research in what they described as, the "unanimous definitions within biology's respectable literature" about the beginnings of human life ${ }^{34}$. Among the defenders, perspectives on human life and its hierarchies were contradictorily expressed: the embryo became 'a subject of its own decisions':

There is n o life in the frozen embryo if there is no hum an intervention ... W e are defending that in the sam e way as an individual with cerebral death can donate orga ns, a frozen em bryo could donate its cells (Mayana Zatz, a Jewish geneticist by back ground and embryonic SC scientist). ${ }^{35}$

Two striking features characterise the debate on this issue in Brazil. First, the differentiation between pre-embryos and embryos, based upon the shaping of the initial neurological system at around day 14 of embryo development, is used internationally to justify ESCR with cells collected at the 'pre-embryo' stage. But this distinction was absent from the discursive strategies deployed. Second, an 
internationally prevalent paradigm shift in conventional perspectives about the initial unit of life had only minor relevance in the Brazilian context. This shift corresponds to that between a social perspective that considers embryos as the initial unit of human life, and that which assigns this place to the stem cell. ${ }^{36}$ (In Brazil, this perspective still generates strong public opposition). Brazilian narratives focused upon drawing a boundary between viable in-vitro surplus embryos as potential initial units of life, and embryos unviable for assisted reproduction, reflecting dominant Christian religious and moral beliefs. ${ }^{37}$

\section{The shaping of a new epistemic scientific community}

SC scientists working with adult cells formed part of both blocs, but expressed opposite views. Those opposed to ESCR framed their arguments in relation to the lack of international therapeutic applications of embryo research, and/or to its risks, and emphasised the potential of adult SCs to substitute for embryonic SCs. Only one scientist in this group mentioned the potential of human induced pluripotent cells (iPS) ${ }^{38}$ to substitute for ESC. ${ }^{39}$ This limited reference to iPS may have partly reflected the fact that international research on these cells was relatively new. Successful derivation of human iPS was only publicly reported in November $2007^{40}$.

Among ESCR supporters, those researchers who only worked with adult SCs indicated their interest in extending their work to embryonic cells because of their higher plasticity and potential to regenerate organs ${ }^{41}$, and only one scientist in this group referred to the future advantages of iPS as they do not involve embryo manipulation ${ }^{42}$. Some speakers explained that what was being used in research was a mass of cells and not the embryo itself ${ }^{43}$. As this camp was trying to defend embryo research experimentation, they adopted an explicit strategy to focus on ESCR, instead of overtly and extensively referring to the potential benefits of iPS.

The 'morality-immorality' of using research embryos was also set against the scientists' moral responsibility by this group:

Responsibility lies within the one that recognises the therapeutic potential of embryo stem cells but blocks or does not prom ote its study. We cannot shirk our responsibility of working with embryonic SCs (Stevens Kastrup Rehen, a Catholic by background and an atheist embryonic SC scientist). ${ }^{44}$

Technical and ethical aspects of ESCs divided Brazilian adult SCs' researchers. However, an intense rivalry did not develop between the two scientific communities, as has been documented in other countries. ${ }^{45}$ Narratives show that the field itself is still under definition locally, as a new and smaller epistemic community is being shaped, namely one that tends towards cooperation between research institutes. ${ }^{46}$ 


\section{Social and gender roles: motherhood, infertility and abortion}

Social and gender attributes, particularly with regard to infertility and motherhood permeated the debates, though for opposite reasons within each camp. The opposing bloc considered that:

To be sure that an em bryo is viable or not, the only way to give it a chance is for it to be im planted. The point is that when several embryos are implanted not all are viable and develop till the end of gestation (Lenize Aparecida Martins Garcia, a practising Catholic and a professor of biology). ${ }^{4}$

The defending bloc framed embryo research donation as a socio-ethical responsibility:

What is ethically correct? To preserve frozen em bryos, even knowing that their probability of generating a hum an being is practically zero, or dona te them for re search that could result in future treatments? (Mayana Zatz) ${ }^{48}$

The embryo was construed as a direct contributor to the wellbeing of present and future generations specially in one narrative (Deborah Diniz , a Catholic by background and an atheist, a leading bioethicist and anthropologist).

Positions upheld by both blocs converged in their disregard for the perspectives of research embryo donors. While one bloc defended the parents' obligation to allow embryos to grow into babies, the other emphasises the parents' social responsibility to support the development of future therapies based on embryo donation for research. The parents' own perspectives on embryo research are absent from these narratives.

Scientists also assumed, without offering evidence, that assisted fertilisation patients would agree to donate to ESCR. Estimates on sources of ESCR are based on the number of surplus embryos frozen within assisted fertilisation clinics, without knowing, whether and under what conditions and for what types of research, parents would consent to donation. Important motivations for embryo research donations, such as research aimed at the advancement of reproductive medicine, infertility treatment and embryo abnormality detection, were not mentioned during the local debates. $^{50}$

Two important aspects of embryo donation for research were excluded from the debate: a) the potential coercive or inducement effects on donations of the doctorpatient or researcher-patient relationship; and b) the potential technical arbitrariness in embryo-grading, resulting from non-standardised classifications between fertility clinics. $^{51,52}$

The opposing camp made a direct association between ESCR and abortion, a practice prohibited and criminalised in Brazil. Pre-existing sociocultural perspectives, transposed from abortion debates, permeated the arguments. References and analogies 
were made to 'pro-life' arguments. ( The foetus was portrayed as feeling pain and influencing the mother's psyche and hormones very early on; the mother as having a very early communication with the embryo/foetus. $)^{53}$

Hegemonic social attributes based on gender relations dominated the debate, including women's social role as mothers and also as research donors. ${ }^{54}$ These attributes are interwoven into a referential framework developed almost exclusively by the scientific and medical establishment, defended as being superior, or the 'only discourse with authority'; ${ }^{55}$ and given priority above other forms of knowledge, including that of the genitors of potential research embryos.

Infertility, for both blocs, consequently becomes a valuable source of biological research materials and is repositioned within culturally hegemonic social perspectives. ${ }^{56}$ Infertile Brazilians, especially women, are directly or indirectly asked to work towards 'the common good'.

\section{National competition in genetics and health biotechnology}

The rhetoric of the debate transmitted a certain hastiness to approve ESCR associated with Brazil's international position in this field. ESCR supporters focused upon the global use of embryonic SCs to develop or test drugs and medicine, intellectual property rights protection and the Brazilian poor future lack of access to international SC-based drugs and therapies. ${ }^{57,58}$ This group argued that the 2004 National Science, Technology and Innovation Plan ${ }^{59}$ had established biotechnology - including SCR - as one of its strategic priorities, thus providing the opportunity to develop advanced technology locally. ${ }^{60}$

One of the main convergence zones between the blocs during the public debates was national pride in the country's SCR with adult cells, particularly its global role:

Brazil is the world champion in relation to the diversity of clinical applications using adult SCs ... it is one of the leading countries in the world that cu res its patients with th ese therapies (Rogerio Pazetti, a practising Catholic and a biologist and adult SC scientist). ${ }^{61}$

Some of the pioneering local scientists in adult SCR formed part of the defence group (e.g. Antonio Campos de Carvalho, director of the National Network of Cellular Therapies and of the National Multicentre Random Trial on Heart Disease). ${ }^{62}$ Strategically, the opponents emphasised the discourse on Brazil's leading role in adult stem cells, to try to ban embryonic stem cell research.

During the debates on Brazil's global competition there were some key omissions. These included: potential public access to the eventual local cellular therapies; the prospective costs of these therapies; future relations with the biotechnology industry; potential ethnic and racial discrimination; ${ }^{63}$ and eventual commercial uses of these therapies for cosmetic ends. ${ }^{64}$ 


\section{Stem cell research debates revisited}

The Brazilian debates show some relevant local trends and social positions in relation to at least the following three topics: forms of scientific, technical and moral construction of discourse and regulation; social views on civil society's engagement; and perceptions on Brazil's contributions to global genetics. These topics will be briefly addressed taking as points of comparison relevant public SCR debates in other contexts and the wider Brazilian health and/or development context.

The Brazilian public debates on SCR are relatively recent compared with most European and other developed countries, ${ }^{65}$ and do not form part of a structured public revision of human reproduction and genetic institutions and regulation. Many countries pioneering ESCR concentrate on the difficulty in establishing adequate regulatory frontiers for research objects that defy traditional rules and codes of practice. ${ }^{66}$ This is also the case in Brazil, in relation to one central aspect of the public debates: the use of viable and unviable embryos for experimentation.

The 'embryo question' plays a dominant role in defining the content of the different local debates. The interpretations made, based on sociocultural and religious backgrounds (root religion or regularly practised religion - as acquired through family background and/or education and not necessarily being practised), determine specificities within these positions. Pragmatic perspectives dominant among defenders of ESCR are supported by ontological positions that are not so clearly defined and, sometimes, juxtapose and articulate elements of different approaches to life within a single argument. Brazilian opponents of ESCR articulate their exploration of biological facts and of related ethical frameworks and ontological references more coherently within their own perspective, but less systematically.

Only sporadic elements of an ontological paradigm shift from the human embryo to the stem cell as the initial unit of life, key to other societies' debates, are found in the Brazilian context. ${ }^{67}$ Also, the definition of hierarchies and grades between types of human research embryos, for example, between viable and unviable frozen and fresh embryos, although addressed by ESCR advocates, does not become a central axis of debates. $^{68}$

However, Brazilian debates largely converge with narratives in other countries' SCR public debates in their utilitarian approach, emphasising the potential service that invitro embryos might offer to society or to specific patients. Even among ESCR opponents, where Catholicism plays a central role in perceptions and narratives, a certain utilitarian perspective also prevails. However, when the Catholic religion is acquired by background and not regularly practised - as reflected in some of the narratives among ESCR defenders - the utilitarian approach apparently becomes even stronger; and it is even more marked among atheists.

Brazilian perspectives on scientific and technical progress tend to deal with scientific discourse as a form of 'authoritative knowledge', and narratives tend to reflect 
structured and quite evenly distributed cultural beliefs on trust in scientific and technological paths. The discursive tactics and strategies used for the construction of new frontiers in this field, reveal the use of dichotomies such as, 'science' and 'nonscience' and 'good' or 'bad' science, which play quite a central role in the controversies, and are supported by abundant references to international practices. However, there is no significant initiative to build a coherent and institutionally referenced scientific, technical and ethical framework that could give rise to distinct new concepts and vocabulary - e.g. that of 'pre-embryos'- which would be useful to establish some uniformity and eventually generate points of inflection in the public debates, ${ }^{69}$ as well as contributing substantially to the design of new regulations.

Politicisation of public health and ethics is a common feature of Brazilian public debates on different health topics. ${ }^{70}$ In the case of ESCR, morality is used as a resort and polarised between: the embryo versus the suffering patients or their families, or the rights of the embryo versus the scientists' responsibilities. The potential patients are represented as being desperate for cures, despite a lack of consultation with some key patient groups and organisations for people with disabilities. For example, the multiple demands posed by international patient organisations, or individuals, defending their condition of disability or sensorial deprivation and their rights to an intergenerational transmission of selective forms of disability have not been addressed by the public debates in Brazil. ${ }^{71}$ This topic could have been discussed at the Supreme Court hearing by having some speakers to counterbalance the dominant perspective in which people with disabilities were portrayed as desperate for new SCR therapies.

Lobbies for and against ESCR try to engage the 'publics' through a 'hype and hope' strategy ( meaning the use of information and emotional tones that exaggerate the benefits and delivery-times of potential therapies and cures and thus 'hype' eventual users' expectations and hopes), ${ }^{72}$ but in significantly different ways. The ESCR defenders' lobby mainly targets patients and families, while the opposition lobby mainly targets anti-abortion and religious groups. Also, Brazilian 'bottom up' public engagement campaigns on SCR are different to those in other countries. They have been based upon short-term lobbying strategies and voluntary public advocacy, rather than upon a stable and solid participation process and institution-building for policy decision-making. ${ }^{73}$

In general, Brazilian patient organisations are smaller than, for example, most US or European equivalents, and are less active and articulate in public debates. ${ }^{74}$ The SCR 'publics' are drawn mainly from a: 'deficit top-down model' ${ }^{75}$ and, even though the Brazilian Government develops public consultation of concerned stakeholders for specific SCR topics, it lacks an appropriate design for an inclusive public consultation strategy. The voices of specific social movements in the public arena ${ }^{76}$ have been reduced to a minimum in past SCR public debates, with some exceptions. ${ }^{77}$ The Brazilian 'publics' are involved in these debates in ways that show a transition and/or disparity between the exercise of civil rights within a representative democracy, and within a direct and participatory democracy. ${ }^{78}$ 
Scientists' narratives on Brazil's global participation in genetics and biotechnology are constructed with reference to the country's international competitiveness and are intended to promote the acceptance of scientific progress in SCR. Cellular therapies are measured in terms of their potential for disease treatment and for the country's competitiveness. This field is seen as an opportunity for Brazil's international expansion, so the country's national success in adult SCR tends to be 'hyped.'

There was an important omission in the construction of the National Congress public debates, the potential commercialisation and distribution of the eventual embryobased cellular therapies, a central issue for an emerging economy that seeks both better public health therapies and greater leadership in the international arena. This topic was not significantly addressed within the SFT public hearing either by the justices or the speakers. Given the rate of local innovation and developments in the area, ${ }^{79}$ it is particularly relevant to focus on this aspect in the future, i.e. the potential participation of the biotechnology and pharmaceutical industries in the development of SCR-based therapies for the public health system.

\section{Acknowledgements}

This article is based on partial findings from a research project under my coordination, supported by the Brazilian National Research Council (CNPq): Capacity-building in Governance: Social Views and Public Debates on Stem Cell Research in Brazil (2010-2011). See, the project's website at: www.govcel.com.br , as well as, L. Acero, Pesquisas e Terapias com Células-Tronco: Governança, Visões Sociais e o Debate no Brasil. Rio de Janeiro: Ed. E-papers Ltd.

I would like to thank the peer reviewers for their helpful comments, and my colleagues on the Post-Graduate Programme on Public Policies, Strategies and Development (PPED), of the Instituto de Economia, at the Federal University of Rio de Janeiro (UFRJ), most especially Prof Lia Hasenclever and Helena Klein for their contributions.

\footnotetext{
${ }^{1}$ Instituto de Economia, Federal University of Rio de Janeiro. lilianaacero2009@gmail.com

${ }^{2}$ For a study of emerging poles of health biotechnology innovation in developing countries, see M. Harvey and A. McMeekin. 2007. Public or Private Economies of Knowledge? Turbulence in the Biological Sciences. London, Edward Elgar. For an overall analysis of local health biotechnology, see M. Ferrer et. al. The scientific muscle of Brazil's health biotechnology. Nature Biotechnology 2004; 20 (5): 19-28.

${ }^{3}$ S. Thomas. 2003. Critical Issues Pertaining to the Gender Dimension of Biotechnology Policy. A paper presented to the Gender Advisory Board, United Nations Commission on Science and Technology for Development, Geneva.

${ }^{4}$ E. Herold. 2007. Stem Cell Wars: Inside stories from the frontline. London, Palgrave MacMillan.

${ }^{5}$ R. Isasi. 2010. Registration of Stem Cell Based Clinical Trials: A Scientific and Ethical Imperative. Stem Cells, Science and Society, World Stem Cell Report 2009, 2010 World Stem Cell Summit, Detroit, MI, Genetics Policy Institute: 24-36; R. Isasi and T.M. Ngueen. The rationale for a registry of clinical trials involving human stem cell therapies. Health Law Review 2008; 16 (2):56-68.

${ }^{6}$ For evidence on the articulation between regulation and health innovation within developing countries see, for example, M. Leach. Understanding Governance: Pathways to Sustainability. STEPS Working
} 
Paper 2, 2007. Brighton, STEPS Centre; M. Leach, I. Scoones and B. Wynne eds. 2005. Science and Citizens: Globalization and the Challenge of Engagement. London, Zed Books.

${ }^{7}$ Described as "discourse regularities" by M. Mulkay. 1993. Rhetorics of hope and fear in the great embryo debate. Social Studies of Science 1993; 23 (4):721-742.

${ }^{8}$ Comissão Técnica Nacional de Biossegurança (CTNBio).

${ }^{9}$ The overall period between 1995 and 2008 also corresponds to different governments, each supporting different socioeconomic models and perspectives on democracy, social participation and national biosecurity policy, under the presidencies of Fernando Henrique Cardoso (1995-2002), and Luiz Ignacio da Silva (Lula) (2003-2010).

${ }^{10}$ For example, inefficient implementation of the new public health system and inefficacies in the prevention and treatment of HIV/AIDS, had already been contested by different civil society organisations.

${ }^{11}$ The public surveillance of in-vitro fertilisation and research embryo use in Brazil is conducted by the National Agency of Vigilance and Sanitary Control (Anvisa) through a series of regulations. The Agency created a data base of in-vitro frozen and fresh embryos (SisEmbrio) available at the fertilization clinics, only in 2009. These are mainly private clinics which are licensed by Anvisa and only further controlled by the non-binding 1992 guidelines from the Federal Medical Council (CFM) and from networks such as Redlara, the Latin American Network of Assisted Reproduction formed by 90 per cent of the Latin American private fertilisation clinics and licensed through peer-review. The regulatory status of the mostly private Brazilian fertilisation clinics that provide embryos for research only through donations involving the informed consent of parents - is far from ideal. Unethical procedures and resistance to informing Anvisa on in-vitro reproductive and research human embryo banking have frequently been denounced by local academics and the press. For further reading on the consequences of these practices for in-vitro fertilisation, as well as for embryonic stem cell research see, for example, L. Acero. 2007. Genetics and Gender: New reproductive technologies in Latin America. In New Genetics, New Identities. P. Atkinson, A. Glasner and E.Greenslade, eds. Routledge, London: 157-176; M. Corrêa. As novas tecnologias reprodutivas: uma revolução a ser assimilada. Physis. Revista de Saúde Coletiva 1997, 7 (1): 60-98. L. Acero. Gender and New Reproductive Technologies within Development. In: W. Hartcourt ed. with MT. Darling and C. Wolbring. New Technologies and Development, Development, Journal of the Society for International Development 2006; 49 (4):135-140.

${ }^{12}$ During later debates in the Senate Chamber, their decision would be reversed and Congress would then take a more definite position on research embryo status. L. Cesarino. Nas fronteiras do "humano": Os debates britânico e brasileiro sobre a pesquisa com embriões. Mana 2007; 13 (2): 1-32; D. Diniz and D. Avelino. 2009. Escenario internacional de la investigación em células madre embrionarias. Revista de Saûde Pública 2009; 43(3): 541-547.

${ }^{13}$ The approach considers egg-fertilisation to determine the beginnings of human life. Cesarino, op.cit. note 12: 12 .

${ }^{14}$ The lobby included well-known public figures, e.g. patients who were former television or sport stars who had either been affected by a severe illness or had become disabled, as well as the following prominent patient groups and organisations for the disabled: The Association of Assistance to Deficient Children (AACD); The Brazilian Association of Spinal Injuries (ABRAME); The Brazilian Association of Muscular Dystrophy (ABDIM); The Brazilian Association of Lateral Esclerosis (ABRELA); The Association of Juvenile Diabetes (ADJ); The Parents and Friends Association of the São Paulo Disabled (APAE de São Paulo); Dorina Nowill Foundation for the Blind.

${ }^{15}$ Patient groups and organisations did not necessarily know about the alliance made between organisational leaders. See, for example, M. Tait Lima. 2009. As concepções dos cientistas brasileiros sobre a tecnociência: um estudo a partir da CTNBio. Master's thesis presented to the Programme on Science and Technology Policy. Campinas,: UNICAMP; R. Scavone. 2008. Audiência Pública realizada na ADI 3510-0: A organização e o aproveitamento da primeira audiência pública da história do Supremo Tribunal Federal. Master's thesis presented at the Escola de Formação, Sociedade Brasileira de Direito Público, São Paulo: SBDP.

${ }^{16}$ M. Mulkay. 1997. The embryo research debate: science and the politics of reproduction. Cambridge, Cambridge University Press: 8 
${ }^{17}$ Article $5, \S 3^{\circ}$ of the newly approved biosecurity law also prohibited the commercialisation of human ESC, a practice considered to be criminal, according to article 15 of the previous 1995 biosecurity law on the selling and buying of tissues, organs or parts of the human body. For those crimes, penalties were envisaged, ranging from, monetary fines to imprisonment, for three to eight years. Article 6 of the new 2005 Biosecurity Law also prohibited human cloning, making it a crime punishable with monetary fines and/or imprisonment and hence, making human therapeutic cloning also illegal. But new embryonic stem cell lines could be produced from surplus in-vitro embryos. The Biosecurity Law did not establish a general and definite regulation for research with human embryos.

${ }^{18}$ This was the first approved Brazilian STF public hearing but not the first requested; one on the case of abortion for anencephalic foetuses was held in August 2008.

${ }^{19}$ See Supremo Tribunal Federal (STF). 2008 b. Transcrições da Audiência Pública da Ação de Inconstitucionalidade (3510-0). STF em Foco: 223: 1-2 www.stfemfoco.org.br, (Accessed 22 March 2010). Carlos Ayres Britto subsequently presided the Public Hearing at the STF.

${ }^{20}$ Specialists were chosen after a wide consultation process held across different institutions. Candidates were nominated by: the attorney-general, responsible for the unconstitutionality case, the Presidency, the National Congress and four stakeholder organizations admitted as amicus curiae: CONECTAS- Centre for Human Rights (CDH), MOVITAE- Movement for Life ( an NGO formed by patients in favour of ESCR and their relatives), the Institute of Bioethics, Human Rights and Gender ANIS and the Brazilian National Conference of Bishops-CNBB.

${ }^{21}$ Scavone, op.cit. note 15: 21.

${ }^{22}$ Supremo Tribunal Federal (STF) 2008 a. Vote of justice Gilmar Mendes. Votos dos Ministros do STF, Seção Notícias: 4. www.stj.jus.br (Accessed 10 August 2010). A distinction is being made between an individual who actively practises a religion and one who belongs to a certain religion because of his/her upbringing, but who does not practise it. This distinction is relevant because, in the last case, the individual has greater freedom to choose whether or not to follow the respective Church's doctrine and guidance on stem cell research.

${ }^{23}$ Ibid. Vote of justice Carlos Britto: 215. (Accessed 10 August 2010).

${ }^{24}$ Ibid. Vote of justice Carlos Britto: 216. (Accessed 10 August 2010).

${ }^{25}$ Ibid. Vote of justice Carlos Britto:216. (Accessed 10 August 2010).

${ }^{26}$ An epistemic community here denotes a network of professionals with expertise and competence in a particular domain and an authoritative claim to policy-relevant knowledge within that domain or issuearea but who might exclude relevant information and bias their views. As described by Haas, these diverse people have a shared set of normative and principled beliefs, shared causal beliefs, shared notions of validity and a common policy enterprise. See P.M. Haas. Introduction. Epistemic communities and international policy coordination. International Organization 1992; 46 (1):1-35. ${ }^{27}$ S. Jasanoff. Introduction: Science and citizenship: a new synergy. Science and Public Policy 2004; 31 (2): 90-94; S. Jassanoff. 2005. Design of Nature: Science and Democracy in Europe and the United States. Princeton, NJ, Princeton University Press.

${ }^{28}$ B. Latour and S. Woolgar. 1978. Laboratory Life: The Social Construction of Scientific Facts. London: Sage; B. Latour 1987. Science in Action: How to Follow Scientists and Engineers through Society. Cambridge, MA, Harvard University Press.

${ }^{29}$ Supremo Tribunal Federal (STF), op.cit.note 19, presentation of Lenice Aparecida Martins Garcia: 223. (Accessed 24 March 2010).

${ }^{30}$ Supremo Tribunal Federal (STF), op.cit. note 19, presentation by Alice Teixeira Ferreira:76, a surgeon and a practicing Catholic 134. (Accessed 24 March 2010).

${ }^{31}$ Supremo Tribunal Federal (STF). 2008 b, op.cit. note 19, Presentation by Rodolfo Acatauassú: 134. (Accessed 24 March 2010).

${ }^{32} \mathrm{An}$ interpretative strategy frequently used for the support of ESCR in different cultural contexts. See, for example, M. Sleeboom-Faulkner. Debates on HESRC in Japan: Minority Voices and their political amplifiers, Science as Culture 2008; 17(1): 85-97; M. Sleeboom-Faulkner with P. Prasanna. The Bioethical vacuum: national policies on human ESCR in India and China. Journal of International Biotechnology Law 2008; 5(6): 221-234. 
${ }^{33}$ Supremo Tribunal Federal (STF), op.cit. note 19, see for example presentation by Patricia Helena Lucas Pranke, a Catholic by background, a pharmacist and ESC scientist from Rio Grande do Sul: 1920. (Accessed 24 March 2010).

${ }^{34}$ See for example Supremo Tribunal Federal (STF), op.cit. note 19, presentation by José Antonio Eça (a psychiatric doctor from São Paulo and a practising Catholic): 105 (Accessed 26 March 2010).

${ }^{35}$ Supremo Tribunal Federal (STF), op.cit. note 19, presentation by Mayana Zatz: 13. (Accessed 27 March 2010).

${ }^{36}$ E. Keller. 1995. Refiguring Life: Metaphors of Twentieth-Century Biology. New York, Columbia University Press.

${ }^{37}$ For a discussion on differences between the local Catholic, Protestant and Yoruba-based (Umbanda and Candomblé) religious positions relating to embryonic stem cell research, see N. Luna.

Religiosidade no Contexto das Terapias com Células-Tronco: uma investigação comparativa entre pesquisadores "iniciantes e iniciados" e seus pacientes. Religião e Sociedade 2008; 28(2): 156-178 and L. Acero. 2011. Pesquisas e Terapias com Células-Tronco; Governança, Visões Sociais e o Debate no Brasil. Rio de Janeiro, E-papers.

${ }^{38}$ Induced pluripotent cells (iPS or iPSCs) are a type of pluripotent stem cell artificially derived from a non-pluripotent cell, typically an adult somatic cell, by inducing a 'forced' expression of specific genes. iPS are similar to natural pluripotent stem cells, such as ESC, in many respects, for example in the expression of certain stem cell genes and proteins, but the full extent of their relation to natural pluripotent stem cells is still being assessed. iPS were first produced in 2006 from mouse cells and in 2007 from human cells. This is considered an important advance in SCR, as it may allow researchers to obtain pluripotent SCs without the use of embryos. They also avoid the issue of graft-versus-host disease and immune rejection, unlike ESCs, because they are derived entirely from the patient.

${ }^{39}$ iPS were also developed locally by the scientist Stevens Rastrup Rehen in 2009 at the Federal University of Rio de Janeiro.

${ }^{40}$ Although a team from the University of Tokyo announced the successful derivation of animal iPS from somatic cells of mice in 2006, articles on human iPS derivation from the US Wisconsin Madison University team, which had a greater impact upon the Brazilian scientific community, appeared later on in 2007, after the local STF public hearing had already been held.

${ }^{41}$ Supremo Tribunal Federal (STF), op.cit. note 19, presentation by Rosalia Otero, a practising Catholic, a medical doctor and an adult SC scientist from Rio de Janeiro: 41. (Accessed 29 March 2010).

${ }^{42}$ Ibid. Presentation by Stevens Kastrup Rehen, a Catholic by background, an atheist and a leading ESC scientist from Rio de Janeiro: 24. (Accessed 28 March 2010).

${ }^{43}$ Ibid. Presentation by Ricardo Ribeiro dos Santos, a Catholic by background and an atheist and an adult SC scientist leading the local Chagas disease team in the State of San Salvador de Bahia of the National Multicentre Random Trial on heart Disease:53. (Accessed 29 March 2010).

${ }^{44}$ Ibid. Presentation by Stevens Rehen: 25. (Accessed 28 March 2010).

${ }^{45}$ B. Prainsack, E. Geesink and S. Franklin. 2008. Guest Introduction Cell Technologies 1998-2008: Controversies and Silences. Science as Culture 2008; 17 (4): 351-362.

${ }^{46} \mathrm{M}$. Ferrer et al, op.cit. note 2: 26.

${ }^{47}$ Supremo Tribunal Federal (STF), op.cit. note 19, presentation by Lenice Aparecida Martins Garcia: 215. (Accessed 12 April 2010).

${ }^{48}$ Ibid. Presentation by Mayana Zatz: 13. (Accessed 10 April 2010).

${ }^{49}$ Ibid. Presentation by Deborah Diniz: 280. (Accessed 25 April 2010).

${ }^{50}$ See for example V. Ferreira, M. Ávila and A. Portella 2007. Feminismo e Novas Tecnologías Reprodutivas, Recife, Edições SOSCORPO and Heinrich Böll Foundation; S. Parry. (Re)Constructing embryos in stem cell research: Exploring the meaning of embryos for people involved in fertility treatments. Social Science \& Medicine 2006; 62 (10): 2349 - 2359.

${ }^{51}$ Scientists largely granted authority for the implementation of decisions on embryo research donations to the in-vitro fertilisation clinics rather than to the parents themselves. In contrast, ESCR opponents regarded assisted fertilisation as embedding new moral values which they considered as a setback for contemporary civilization. 
${ }^{52}$ In Brazil, these classifications do not necessarily follow national regulatory standards and private fertility clinics are not closely monitored. See for example Acero, op.cit. note 11: 138 and Acero, op.cit. note 11: 163.

${ }^{53}$ See, Supremo Tribunal Federal (STF), op.cit. note 11. Presentation by Lilian Pinero Eça, a practising Catholic, a biologyst and an adult SC scientist: 75. (Accessed 15 April 2010)

${ }^{54}$ For a broader analysis of traditional gender roles on reproduction and motherhood as transposed to embryonic stem cell research and to the gift relation in donation see for example D. Dickenson. 2007. Property in the Body: Feminist Perspectives. Cambridge, Cambridge University Press.

${ }^{55}$ B. Jordan. 1997. Authoritative Knowledge and its Construction. In Childbirth and authoritative knowledge. L. Davis-Floyd and C. Sargent, eds. Berkeley, University of California Press: 55-79.

${ }^{56}$ S. Parry. (Re)Constructing embryos in stem cell research: Exploring the meaning of embryos for people involved in fertility treatments. Social Science \& Medicine 2006; 62 (10); 2349 - 2359.

${ }^{57}$ Supremo Tribunal Federal (STF), op.cit., note 19. See for example presentation by Rosalia Mendes Otero, a practising Catholic, a doctor and an adult SC scientist: 41. (Accessed 13 April 2010).

${ }^{58}$ The discussion of medical alternatives to cellular therapies was limited to a comparison with organ transplants, focusing on the delays, risks, costs and other inconveniences for patients.

${ }^{59}$ As agreed at the Second Conference on Science, Technology and Health Innovation in 2004. The Plan has to be applied jointly between the Ministries of Science and Technology, Health, Industry and Commerce, and to have the support of the National Commission on Ethics in Research (CONEP).

${ }^{60}$ Supremo Tribunal Federal (STF), op.cit. note 19. Presentation by Moisés Goldbaum, epidemiologist and policy-maker, Secretary of Science, Technology and Strategic Inputs at the Ministry of Health between 2005 and 2007:180. (Accessed 23 April 2010)

${ }^{61}$ Ibid. Presentation by Rogerio Pazetti:159-160. (Accessed 20 April 2010)

${ }^{62}$ Supremo Tribunal Federal (STF). 2008 b. op.cit. note 19. Presentation by Antonio Carlos de Carvalho, a Catholic by background, a medical doctor and a leading adult SC scientist:195. (Accessed 25 April 2010)

${ }^{63}$ More specifically, ethnic and racial diversity of embryonic stem cell lines would be very important for the local success of research and for wide public access to eventual cellular therapies. In the case of Brazil, source variety becomes even more important, given the ethnic and racial diversity of its population.

${ }^{64}$ See for example S. Franklin and L. Kaftantzi. Industry in the Middle: Interview with Intercytex Founder and CSO, Dr Paul Kemp. Science as Culture 2008; 17 (4): 449-456.

${ }^{65}$ For analysis of ESCR public debates in European countries, see for example, for the UK: S. Franklin. 1999. Making representations: the parliamentary debate on the Human Fertilization and Embryology Act. In Technologies of Procreation: Kinship in the Age of Assisted Conception. J. Edwards et al, eds. London, Routledge: 38-52; Mulkay, op.cit. note 7; Mulkay, op.cit. note 16. For France: G. Maio. The embryo in relationship: A French debate on SCR. Journal of Medicine and Philosophy 2004; 29 (5):583-602. For Germany: S. Sperling. Converting Ethics into Reason: German Stem Cell Policy Between Science and the Law. Science as Culture 2008; 17 (4): 363-375. For non-European countries, E.S. Kim. Heterogeneous Assemblages of Bioethics and Science: The pre-embryo debate in America. New Genetics and Society 2008; 27 (4): 323-337; M. Sleeboom-Faulkner. Debates on HESRC in Japan: Minority voices and their political amplifiers. Science as Culture 2008; 17 (1): 85-97.

${ }^{66}$ See for example N. Brown. 'Beasting' the embryo: The metrics of humanness in the trans-species embryo debate. Biosocieties 2009; 14(2-3): 147-163; S. Parry.2010. Interspecies Entities and the Politics of Nature. In Nature After The Genome. S. Parry and J. Dupré, eds. Oxford: Blackwell: 18-42. ${ }^{67}$ In Britain, this shift has been described as the hegemonic feature of controversies. See for example Parry, op. cit. note 56: 2351.

${ }^{68}$ Nor does the definition of differences between human therapeutic and reproductive cloning that appears frequently in other ESCR debates. See for example Brown, op.cit. note 66: 147-163; S. Parry. The politics of cloning: Mapping the rhetorical convergence of embryos and stem cells in parliamentary debates. New Genetics and Society 2003; 22 (2): 177-200. A possible explanation for this lack of distinction is that ESCR proponents avoided further potential controversies with their opponents, among whom therapeutic cloning might have evoked embedded cultural fears about human reproductive cloning. 
${ }^{69}$ See for example Brown, op.cit. note 66: 159; Parry, op.cit. note 68:197.

${ }^{70}$ For example, public debates on HIV/AIDS and on anencephalic abortion, D. Diniz et.al. A magnitude do aborto por anencefalia: um estudo com médicos. Ciência e Saúde Coletiva 2009; 14 (1): 38-54 ; ANIS.2004 Anencefalia. O pensamento brasileiro em sua pluralidade. Brasilia, ANIS; B. Coriat. 2008. The political economy of HIV/AIDS in developing countries: TRIPS, Public Health Services and Free Access. Cheltelham, Edward Elgar Publishing Ltd.

${ }^{71}$ See for example D. Davis. 2001. Genetic Dilemmas: Reproductive Technology, parental choices and children's futures. London: Routledge.

${ }^{72}$ See for example P. Martin, A. Brown and M. Kraft. From Bedside to Bench? Communities of Promise, Translational Research and the Making of Blood Stem Cells. Science as Culture 2008; 17 (1): 29-41; P. Martin, M. Brown and A. Turner. Capitalizing hope: The commercial development of umbilical cord blood stem cell banking. New Genetics and Society 2008; 27 (2): 127-143.

${ }^{73}$ For an extended analysis of this aspect see Acero, op.cit. note 1: 250-283; and for an analysis of the role played by public engagement with new reproductive technologies, see for example C. Fonseca. A participação leiga nos rumos da ciência: de embriões a maternidade assistida". Saúde e Direitos Humanos 2009 (Brasília); 5 (5): 127-142.

${ }^{74} \mathrm{An}$ important exception is that of HIV/AIDS patients, relatives and activists, many grouped in NGOs that have become highly influential in the country over the last decade.

${ }^{75} \mathrm{~A}$ model where lay publics are considered to possess a deficit of knowledge and are treated as passive recipients of the information transmitted through public training and education programmes. See for example B. Wynne. 1995. Public Understanding of Science. In Handbook of Science and Technology Studies. S. Jasanoff et. Al, eds. Thousand Oakes, CA: Sage: 44-58; A, Irwin and B. Wynne 1996. Introduction . In: Misunderstanding Science? The Public Reconstruction of Science and Technology. A. Irwin and B. Wynne, eds. Cambridge: Cambridge University Press: 35-68. UK academics dealing with governance, tend to be critical, either of the way in which public engagement is carried out, or of its results. See for example B. Wynne. Public Engagement as a Means of Restoring Public Trust in Science: Hitting the Notes, but Missing the Music? Community Genetics Cambridge 2006; 9 (3): 211-220; A. Irwin. The politics of talk: coming to terms with the "new" scientific governance. Social Studies of Science 2006; 36 (2):299-320.

${ }^{76}$ For example, of the women's movement, Afro-Brazilians, indigenous populations, consumer associations and health NGOs.

${ }^{77}$ Exceptions include, at least, five feminist and two law-related organisations that played a very active role in these debates: Ser MULHER, Católicas pelo Direito a Decidir, Rede Feminista de Saúde and $A N I S$ (of the women's movement); CRIOLA (feminist NGO representing the Afro-Brazilian movement), CONECTAS and PRO BONO (lawyers' associations for the defence of human and community rights).

${ }^{78}$ This situation is representative of a wider social phenomenon in Brazil than that pertaining to SCR public debates. For a more general discussion, see for example F. Pereira. Coronelismo, clientelismo e a política de direita. Le Monde Diplomatique - Brasil 2010; 3 (34): 8; and for a positive analysis of the role played by laypeople in local health councils, see for example S. Gerschman and S. Os, Conselhos municipais de saúde. Atuação e Representação das Comunidades Populares. Cadernos de Saúde Pública 2004; 3: 1670-1681.

${ }^{79}$ For an account see for example Acero, op.cit. note 11. 